PontIFícIA UNIVERSIDADE CATÓLICA DO RIO DE JANEIRO

O modelo de franquias no Campeonato Brasileiro de League of Legends

João Carlos Camelo dos Santos

Trabalho de Conclusão de Curso

Centro de CIÊnCIAS SOCIAIS - CCS

DePARTAMENTO de AdMINISTRAÇÃo

Graduação em Administração de Empresas 
João Carlos Camelo dos Santos

\section{O modelo de franquias no Campeonato Brasileiro de League of Legends}

Trabalho de Conclusão de Curso

Trabalho de Conclusão de Curso, apresentado ao programa de graduação em Administração da PUC-Rio como requisito parcial para a obtenção do titulo de graduação em Administração.

Orientador(a) : Marco Aurélio de Sá Ribeiro

Rio de Janeiro, novembro de 2019. 


\section{Resumo}

CAMELO, João Carlos. O modelo de franquias no Campeonato Brasileiro de League of Legends. Rio de Janeiro, 2019. Número de páginas 40. Trabalho de Conclusão de Curso - Departamento de Administração. Pontifícia Universidade Católica do Rio de Janeiro.

O setor de videogame está bastante movimentado no Brasil, com empresas investindo e entrando no mercado, fazendo seus produtos, colocando dublagens e legendas em português para atrair o público brasileiro. Dessa forma, jogos com características competitivas começaram a se tornar muito famosos, criando torneios profissionais no qual atletas competem para saber qual equipe é melhor, esses jogos levam o nome de Esports. Várias dessas modalidades foram estabelecidas no país, porém o League of Legends é o que mais desperta atenção ao público com o torneio chamado de CBLOL. Entretanto, a empresa responsável pelo torneio pensa em evoluí-lo, estabelecendo um modelo de negócio nunca usado no território nacional, movido pelo sucesso obtido fora do país.

Palavras-chaves

Esports, franquia, estratégia, League of Legends 


\section{Abstract}

The video game industry is very busy in Brazil, with companies investing and entering the market, making their products, putting voiceovers and subtitles in Portuguese to attract the Brazilian public. Games with competitive characteristics began to become very famous, creating professional tournaments where athletes compete to know which team is better, these games take the name of Esports. Several of these modalities have been established in the country, but the League of Legends is the one that draws the most attention from the public with the tournament called CBLOL. However, the company responsible for the tournament is thinking of evolving it, establishing a business model that was never used in the national territory, driven by the success obtained abroad.

Key words

Esports, franchise, strategy, League of Legends 
1. Apresentação do tema 1

1.1. Introdução 1

1.2. Campeonatos de E-Sports 2

1.3. Estruturação dos campeonatos 3

1.4. Questão do estudo 5

1.5. Objetivo Final 5

1.6. Delimitação e foco do estudo 5

1.7. Relevância 5

2 Referencial Teórico 6

2.1. Esports 6

2.2. League of Legends $\quad 7$

2.3. Franquias 7

2.3.1. Franquias nos E-sports 8

2.4. Avaliação do ambiente externo de uma empresa 10

2.4.1. Ameaça de entrada 11

2.4.2. Ameaça de rivalidade 11

2.4.3. Ameaça de substituto 11

2.4.4. Ameaça de fornecedores 12

2.4.5. Ameaça de compradores 12

2.5. Avaliação das capacidades internas de uma empresa 13

2.5.1. O modelo VRIO 13

2.5.2. A questão do valor 14

2.5.3. A questão de raridade 14

2.5.4. A questão da imitabilidade 15

$\begin{array}{ll}\text { 2.5.5. A questão da organização } & 15\end{array}$

3. Metodologia 17

$\begin{array}{ll}\text { 3.1. Método de pesquisa } & 17\end{array}$

3.2. Universo e amostra 17

3.3. Coletas de dados 17

3.4. Procedimento e tratamento de dados 18 
4 . Apresentação e análises dos resultados

4.1. O Circuito Brasileiro de League of Legends 19

4.2. O modelo de franquias no CBLOL 20

4.3. Análise ambiental do CBLOL 22

4.3.1. Ameaça de novos entrantes 22

4.3.2. Ameaça de rivalidade $\quad 25$

4.3.3. Ameaça de substitutos 26

4.3.4. Ameaça de compradores 27

4.3.5. Ameaças de fornecedores 30

4.4. Análise VRIO do CBLOL 31

4.4.1. Valor 31

4.4.2. Raridade 32

4.4.3. Imitabilidade $\quad 32$

4.4.4. Organização 33

4.5. Análise VRIO franquias no CBLOL 35

4.5.1. Valor do modelo de franquia 35

4.5.2. Raridade no modelo de franquias 36

4.5.3. Imitabilidade no modelo de franquias 36

4.5.4. Organização no modelo de franquias 37

5. Conclusão 38

6. Referências Bibliográficas 40

6.1. Questionário 44 


\section{Apresentação do tema}

\subsection{Introdução}

Em 1972, a empresa Atari foi fundada e revolucionou aquele tempo criando um videogame para arcade chamado Pong. A premissa era simples, simular um jogo de ping pong em um aparelho eletrônico que possuía um monitor e controles para poder jogá-lo, sendo assim o primeiro jogo a ter retorno lucrativo da história. Tudo começou com a empresa instalando seu produto em um bar em São Francisco, Estados Unidos, que ficava ao lado de sua sede. O sucesso foi enorme que decidiram comercializar as máquinas para vários estabelecimentos do país. A popularidade era tanta que alguns aparelhos paravam de funcionar devido ao alto número de fichas colocadas em partidas. No Pong o jogador pode jogar sozinho ou em dupla, o chamado multiplayer, e era nesse modo de jogo onde a diversão era maior, assim a competição nos videogames começava a ganhar forma. Desde então, a indústria foi se desenvolvendo e evoluindo, com a chegada dos videogames domésticos, cada vez mais tecnológicos e desafiadores. Dessa maneira, as pessoas preferiam ficar em casa com seus jogos do que ir a algum lugar que possuísse algum fliperama para jogar, sendo assim a indústria dessas máquinas de videogames foram vendendo cada vez menos até quebrar.

\section{Gráfico 1 - Receita de vendas de videogames arcades}

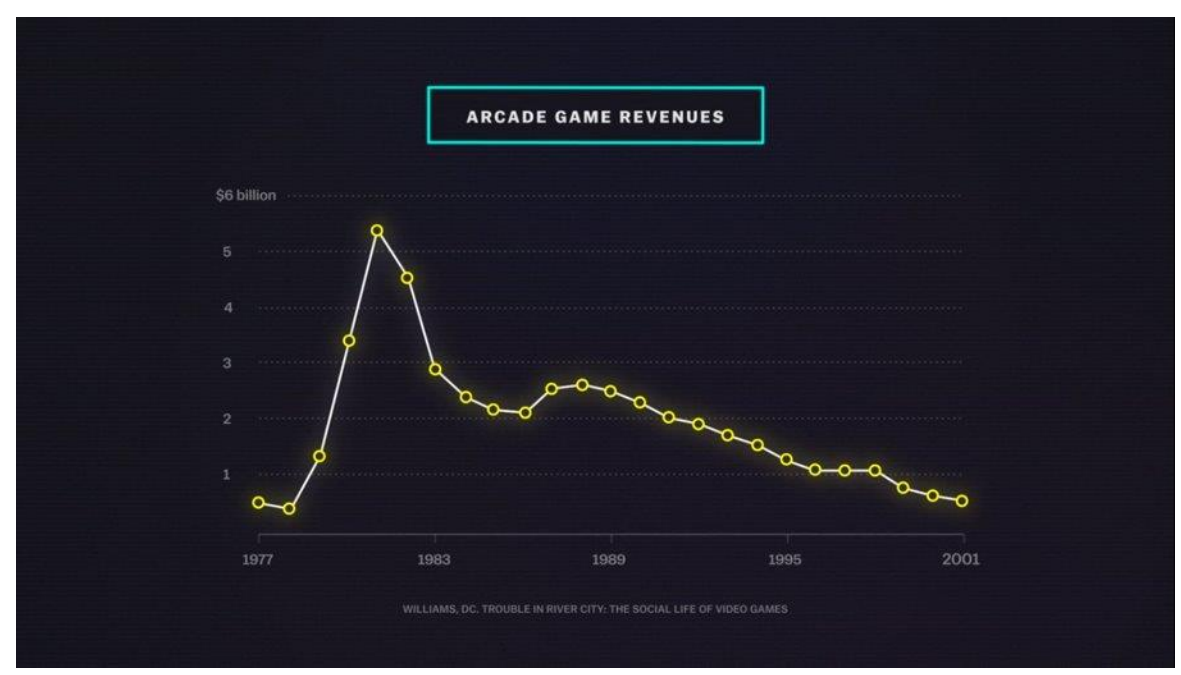

Fonte: Netflix, 2017 
Dentro desse cenário, jogos competitivos e torneios começaram a aparecer, levando entretenimento para quem jogava e para quem assistia. Alguns exemplos são jogos de luta como Street Fighter, até coletivos como Counter Strike e League of Legends.

\subsection{Campeonatos de E-Sports}

Desde o Atari que esse meio vem se desenvolvendo, com eventos onde as pessoas competiam entre si. No entanto, o evento que é considerado o início dos Esports aconteceu em 1997 no World Congress Center, uma competição do jogo Quake, que continha os 16 melhores jogadores de um número total de 2 mil inscritos. O vencedor foi Dennis Fong, mais conhecido como "Thresh", e seu prêmio, uma Ferrari 328 GTS que pertencia ao dono do jogo. Assim as competições foram ficando maiores, envolvendo prêmios mais atraentes, patrocinadores que querem manter contato com os seus consumidores e público interessado em se entreter com os jogos.

Em 2019, diversos torneios consolidados acontecem ao redor do globo, saindo de modalidades de jogos de celulares como Clash Royale e YU-GI-OH Duel Links, até os de computadores como Counter Strike e League of Legends. Um campeonato se destaca pela sua altíssima premiação, e todo ano bate recordes; o torneio mundial de Dota 2 do ano de 2019, chamado de The International, premiou os participantes com $\$ 34.330 .068$ de dólares, sendo que a equipe campeã desembolsou uma quantia de $\$ 15.590 .567$ de dólares.

Em 2018, a final do mundial de League of Legends alcançou um número de 99,6 milhões de espectadores únicos, com pico de 44 milhões de pessoas assistindo simultaneamente. Isso comprova o quão os Esports estão premiando bem os jogadores e o quanto de audiência têm movimentando milhões de pessoas pelo mundo.

A visibilidade se tornou muito relevante, atualmente o CBLOL, campeonato brasileiro de League of Legends é patrocinado pela Gillette. Um dos times participantes é o Flamengo, sendo o vencedor do campeonato de 2019 realizado na Arena Jeunesse, que teve um pico de 316 mil pessoas assistindo simultaneamente pelas redes Youtube e Twitch, o público presente de mais de 9 mil pessoas, além da audiência do SporTV que não foi divulgada. 
Figura 1 - Números da final do mundial de 2018 de League of Legends

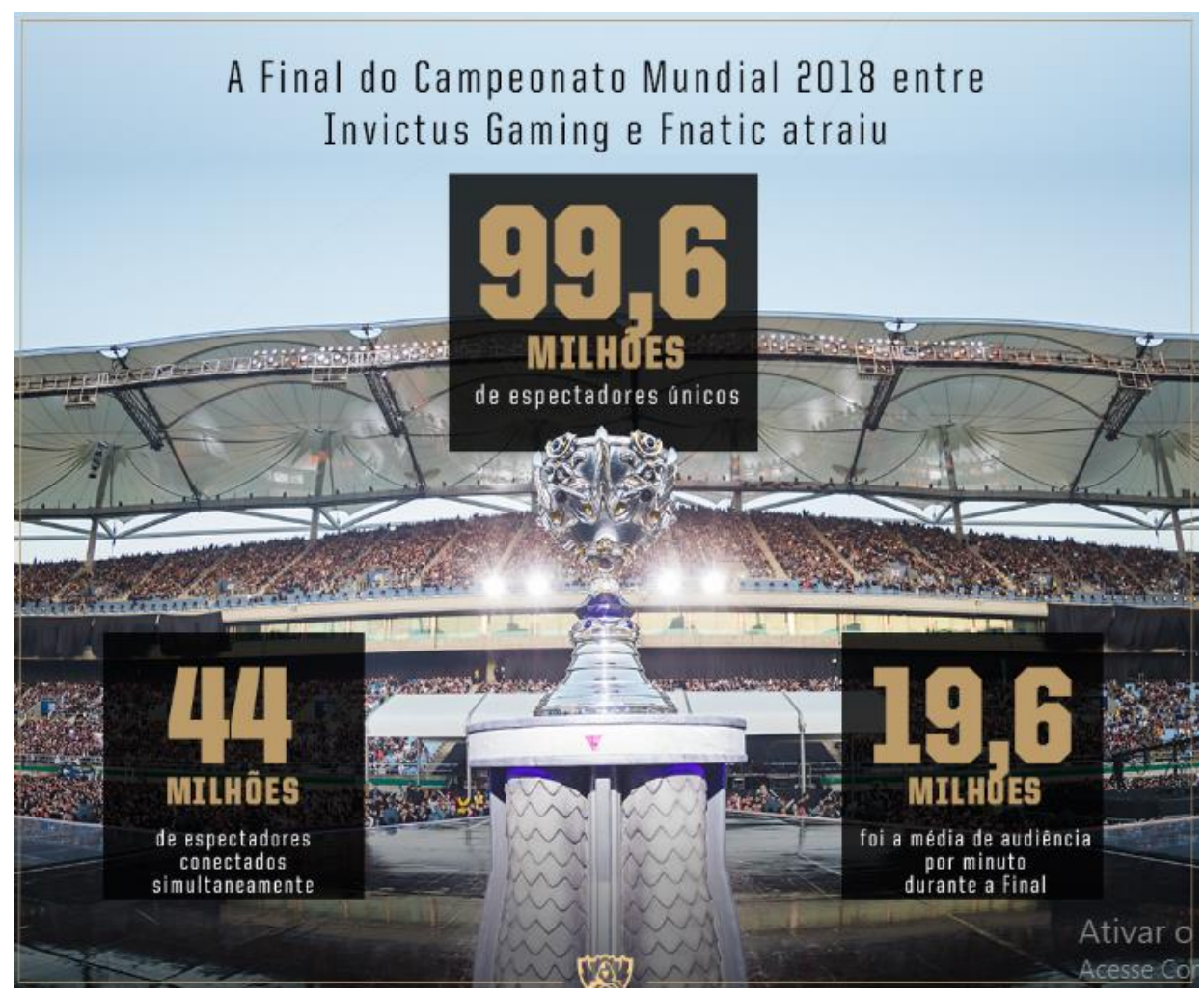

Fonte: LoL Esports BR, 2018

\subsection{Estruturação dos campeonatos}

Os campeonatos de Esports estão tendo cada vez mais audiências e públicos envolvidos nas redes sociais e até em reportagens de jornais famosos. As diversas modalidades estruturam de modo diferente a realização de seus campeonatos. Por exemplo, o Counter Strike, jogo eletrônico de tiro em primeira pessoa, que consiste em rodadas nas quais equipes de cinco pessoas de contra terroristas e terroristas batalham entre si até que uma elimine a outra, também podendo vencer a partida detonando ou desarmando uma bomba. Durante o ano diversos torneios acontecem no mundo tendo a presença das equipes, e a cada 3 meses a Valve, dona do jogo, realiza um campeonato grandioso, chamado de Major convidando as melhores equipes atualmente para participar. Essas equipes são de diferentes países, contendo times dos Estados Unidos, Europa e até mesmo do Brasil. O evento é realizado em uma cidade escolhida, onde todos 
os jogos são realizados presencialmente, com os jogadores no palco e um telão transmitindo para o público.

O League of Legends já é diferente, em cada região do mundo que tem um servidor do jogo há um torneio local, como o CBLOL, o campeonato brasileiro de League of Legends. Ele é realizado com oito times que se enfrentam em uma primeira etapa de pontos corridos, todos as rodadas são realizadas em estúdio presencial, para que não haja vantagens de um time para o outro. No final dessa etapa são realizados os chaveamentos, até que restem dois times para a grande final, acontecendo em um local no Brasil. Este ano a final aconteceu na Jeunesse Arena no Rio de Janeiro, consagrando o Flamengo o campeão de 2019.

Em 2017, a empresa Blizzard Entertainment começou uma revolução que levaria o mundo do esports a mais uma evolução, foi implementado um sistema de franquia no jogo que é dona, Overwatch. Os Esports são caracterizados pelas empresas donas produzirem os jogos, distribuírem e transmitirem, além de serem donas dos campeonatos, eliminando stakeholders. Dessa forma, a Blizzard criou a Liga Overwatch e a franqueou, vendendo doze vagas para equipes que quisessem adquiri-las, no valor de US\$20 milhões cada. Dessas equipes, nove são dos Estados Unidos, sendo um deles de propriedade de Robert Kraft, dono do time de futebol americano New England Patriots. Outras duas equipes da Ásia e uma da Europa fecham as vagas da liga. O campeonato consiste em dois grupos de seis times, que se enfrentarão em 40 jogos até a realização de um mata-mata, restando dois para a grande final. Nenhum time é rebaixado no final, caindo de divisão, é um modelo que tem maior estabilidade para as organizações poderem investir e arriscar o que acham necessário. Assim, há maior participação das empresas, já que são donas de uma parte da liga, tendo maiores benefícios e ganhos.

Os proprietários dos times terão direito a participação nos patrocínios, ingressos e direitos de transmissão. As equipes receberão uma parte de todos os ganhos com a liga. Outra forma de gerar receita será por meio da venda de itens dos times, que receberão $50 \%$ do valor. Cada franquia terá o direito de organizar cinco eventos amadores, por ano, em seu território. Toda a renda gerada nestes eventos ficará para a equipe organizadora (MyCNB, 12 julho 2017). Além das premiações, destinadas aos times que ficarem melhores classificados, tendo o campeão ganhando o maior montante de dinheiro e as demais quantias menores. 
Logo após a Blizzard, a Riot Games, dona do League of Legends seguiu esse modelo de franquia em algumas ligas realizadas pelo mundo, como no campeonato americano, que teve três vagas compradas por times da NBA, uma das ligas mais importantes do mundo. No campeonato europeu, a equipe de futebol, Schalke 04 também adquiriu uma vaga, se tornando franqueado. Atualmente, em 2019, a empresa começa a planejar e a conversar com as organizações para que esse mesmo modelo chegue ao Brasil.

\subsection{Questão do estudo}

Este trabalho busca responder a questão: o modelo de franquias no Circuito Brasileiro do League of Legends é a melhor estratégia?

\subsection{Objetivo Final}

Diante dessa evolução dos Esports, em questão de estrutura e audiência, pretende-se analisar se o sistema de franquias em ligas de Esports é uma boa alternativa para o mercado brasileiro.

\subsection{Delimitação e foco do estudo}

O estudo busca entender o cenário de League of Legends no Brasil, no quesito do Circuito Brasileiro de League of Legends (CBLOL) se transformar em uma liga franqueada e deixar o atual sistema de lado. Busca entender como o setor funciona, evidenciando as vantagens e desvantagens dessa estratégia ser aplicada.

\subsection{Relevância}

Este estudo mostrará às empresas donas de jogos de Esports no mundo, se no mercado brasileiro é benéfico investir nas ligas dessas modalidades e também as organizações donas de times se é interessante atuar nesse segmento. 


\section{Referencial Teórico}

\subsection{Esports}

"Os esportes eletrônicos são definidos por serem competições disputadas em jogos eletrônicos em que os jogadores atuam como atletas profissionais de esportes tradicionais e são assistidos por uma audiência presencial e/ou online, através de diversas plataformas de stream online ou TV (Confederação Brasileira de Esports, 2017)." Assemelha-se com os esportes tradicionais por causa da competição, trabalho em equipe ou jogo individual, mas não requer tanto esforço físico já que os praticantes dependem de uma máquina.

Assim, como nos esportes tradicionais os Esports também possuem diversas modalidades que se diferenciam uma das outras. Existem os jogos de luta, que normalmente são disputados entre duas pessoas que têm a sua disposição alguns personagens a escolha, cada um com habilidades únicas, se enfrentando em um combate com o objetivo de zerar os pontos de vida do oponente. Outra categoria são os FPS (First Person Shooter), que no geral consiste em duas equipes se enfrentando em um território, tentando eliminar os adversários utilizando armas, bombas e mais recursos até que reste somente uma equipe.

Com o tempo, mais esses Esports ganham fama, atraem adeptos que, além de jogarem, assistem a torneios e a jogadores que fazem transmissão online, levando entretenimento através de gameplay, ou seja, transmitindo as partidas que jogam. Um exemplo de streamer, pessoa que faz transmissão ao vivo, é o brasileiro Felipe "YODA" Noronha, jogador de League of Legends, ele conseguiu chegar a marca de 114 mil espectadores assistindo-o simultaneamente.

Com mais audiência, as produtoras dos jogos conseguem patrocínios para os torneios, premiações maiores são oferecidas e, consequentemente, mais pessoas interessadas aparecem, criando organizações para disputarem as ligas, capacitando os jogadores para que possam viver de jogar videogame. Esse modelo já vem sendo implementado há algum tempo, chamando atenção de grandes nomes dos esportes tradicionais, como por exemplo, o Flamengo, time de futebol famoso no Brasil, que criou uma equipe de League of Legends em 
2018, se consagrando campeão do Campeonato Brasileiro de League of Legends em 2019 na final disputada na Jeunesse Arena, levando o prêmio de $\mathrm{R} \$ 70$ mil.

\subsection{League of Legends}

O MOBA é uma das modalidades mais famosas do mundo no cenário de Esports, o gênero se baseia em duas equipes de três ou mais jogadores que tem o objetivo de destruir a estrutura central do outro time, para isso eles têm à disposição alguns personagens que possuem habilidades distintas, fazendo com que os participantes criem várias estratégias para poderem atingir o objetivo final.

O League of Legends se enquadra nessa categoria, nos mostrando números impressionantes de jogadores. Em 2016, a empresa desenvolvedora e dona do jogo, Riot Games, divulgou que, mensalmente, o jogo tinha 100 milhões de usuários únicos no mundo. Em 2019, foi revelado que o pico de jogadores simultâneos online é de 8 milhões de pessoas, fazendo um comparativo com o competidor direto do jogo, o DOTA chegou a marca de 917,4 mil pessoas, não conseguindo chegar a 1 milhão de pessoas, isso mostra a força que o jogo possui.

Criado em 2009, o LOL (League of Legends) estruturou seus campeonatos de maneira que cada região que atua tenha sua liga principal, ou seja, cada lugar do mundo que tem um servidor do jogo possui um campeonato grande onde equipes profissionais competem para se consagrarem campeões. No Brasil a liga se chama Campeonato Brasileiro de League of Legends, o CBLOL, que teve em 2019 o Flamengo como vencedor, com a final sendo disputada na Jeunesse Arena com um público de mais de 8 mil presentes, e 300 mil espectadores únicos acompanhando por plataformas de streaming, além da transmissão do SPORTV, que não teve números divulgados até o momento.

\subsection{Franquias}

O modelo de negócios de franquias é bastante utilizado por empresas que querem se expandir e crescer rapidamente, seja pelo país na qual atua ou até mesmo no mundo. Uma empresa que é franqueada de outra terá o direito de utilizar a marca da franqueadora, comercializando seus produtos e serviços, mas 
seguindo um padrão de qualidade estipulado, para não modificar tanto o negócio.

Por definição "esse modelo se caracteriza pela existência de um contrato, no qual uma empresa, detentora de uma marca ou patente (franqueador), utiliza o sistema de franquias para expandir seus negócios, concedendo a outros (franqueados) o direito de uso de sua marca ou patente e de exploração comercial do que tiver sido desenvolvido ou testado por ela. Para reproduzir corretamente o modelo e se beneficiar de um negócio experimentado e bemsucedido, o franqueado deverá receber orientação para a instalação e operação da unidade franqueada, mantendo o padrão exigido e remunerando a franqueadora pela concessão dos direitos e pela transferência desses conhecimentos (SEBRAE, 2018)."

Um exemplo de funcionalidade do modelo no mundo real é do Mc Donald's, o franqueado obtém o direito de utilizar da marca, porém precisa seguir algumas regras para o negócio se manter igual aos outros franqueados, como por exemplo, no modo de montar a cozinha, o preparo dos alimentos, estrutura do restaurante e assim por diante. Dessa forma, um novo Mc Donald's nasce, dando lucro para quem comprou o direito de franquear e pagando Royalts para a matriz principal.

\subsubsection{Franquias nos E-sports}

Franquias também são implementadas no mundo dos esportes eletrônicos, de um modo parecido com o que acontece nas ligas esportivas norte americanas, como na NBA e na NFL. A Riot Games, dona do jogo League of Legends, implementou esse modelo nas suas principais ligas no mundo, sendo uma delas na Europa, funcionando da seguinte forma: O torneio de LoL é disputado por dez equipes, que jogarão entre si durante um período de tempo, até que duas se classifiquem para a final, restando apenas o campeão. Dez vagas foram vendidas a empresas, fazendo com que elas se tornem donas também do campeonato. Segundo a revista Forbes a quantia mínima para uma empresa nova adquirir uma vaga é de $€ 10.5$ milhões. No entanto, para equipes que já estavam na competição antes desse modelo entrar em vigor, a menor quantia é de $€ 8$ milhões. Dessa maneira, o último colocado deixa de ser rebaixado para a segunda divisão, extinguindo o torneio de acesso, criando uma maior estabilidade para os times, já que nenhum poderá deixar a competição. $O$ campeonato da segunda divisão é substituído por outro, onde cada equipe 
presente na liga principal tem uma vaga, assim esse torneio serve como teste, revelando novos jogadores.

Outros padrões foram exigidos, como um salário mínimo aos jogadores estipulado em $€ 60$ mil anuais e contratos de duração de três anos, podendo ser renovado depois, caso as organizações consigam se manter nos padrões de qualidade. A forma de lucro da competição também muda, os lucros gerados são repartidos em três partes: $35 \%$ para os atletas, 32,5\% para a Riot Games e $32,5 \%$ para as franquias. A receita vem por parte dos patrocinadores da competição e de ingressos vendidos, já que todas as partidas são disputadas em um ginásio na Europa, com todos os jogadores presentes, usando cada computador com as mesmas configurações, sem que qualquer pessoa tenha vantagem sobre outra. Outra forma dos times lucrarem são as premiações, tendo o campeão ganhando o maior valor e os demais participantes adquirindo quantias menores, proporcionais a sua colocação no torneio. As equipes também ganham por patrocinadores de fora, empresas que investem para aparecerem nas camisas e produtos dos times, usando a visibilidade do torneio para aparecerem ao público alvo. Exemplos de patrocinadores no Brasil são a Coca Cola e Vivo que patrocinam respectivamente a Pain e a Keyd Stars.

Exemplos de clubes e organizações esportivas que entraram no negócio da Riot Games são: o clube alemão Schalke 04, que comprou uma das franquias da liga europeia e as organizações das ligas americanas de basquete, Golden States Warriors, Cleavelend Cavaliers e Houston Rockets, cada um adquirindo uma vaga na liga americana de League of Legends.

Em 2019, uma reportagem apurada pelo SporTV, a Riot Games começou a procurar as principais organizações brasileiras para discutir a mudança de modelo. Atualmente, o CBLOL é disputado por oito equipes, sendo que a última colocada é rebaixada para a segunda divisão, já o primeiro colocado da segunda vai disputar o Campeonato Brasileiro de League of Legends.

A desenvolvedora é motivada pelo sucesso ocorrido em suas outras ligas de maior importância e pela alta audiência que o mercado brasileiro possui. Em 2018, o número pessoas entusiastas em Esports era de 7.6 milhões, ou seja, assistem conteúdo relacionado a Esports mais de uma vez por mês, é o terceiro maior mercado, perdendo apenas para China e Estados Unidos. O número de pessoas que assistem Esports ocasionalmente é de 10.7 milhões, param para assistir se estiver passando na televisão ou por algum motivo específico, ao total temos 18.3 milhões de pessoas no Brasil que tem contato com esse tipo de entretenimento. 


\section{Gráfico 1 - Audiência de Esports no mercado brasileiro}

occasional Viewers

ESPORTS ENTHUSIASTS

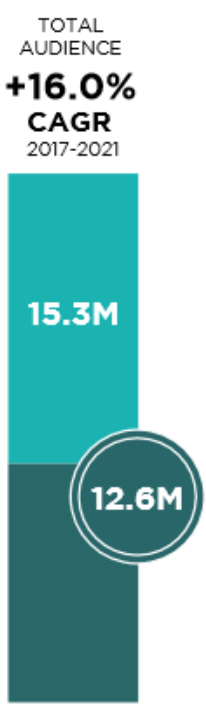

2021

Fonte: Newzoo, 2018

O setor já despertou interesse do famoso jogador de futebol brasileiro, Ronaldo Nazário, que comprou metade de uma equipe de League of Legends, chamada de CNB, que atua pelo CBLOL. Outro investidor de peso é o Flamengo que formou um time e se consagrou campeão da modalidade em 2019. O caminho parece próspero para a Riot Games implementar o modelo de franquia. Mas uma análise do mercado é precisa para saber as condições do mercado, se realmente é favorável.

\subsection{Avaliação do ambiente externo de uma empresa}

Para a Riot Games poder saber como se encontra o mercado que ela pretende atuar e poder mapeá-lo adequadamente, será necessária uma análise de cinco forças desenvolvido pelo professor Micheal Porter, "que identifica as cinco ameaças mais comuns que as empresas enfrentam em seus ambientes competitivos locais e as condições sob as quais essas ameaças têm maior ou menor probabilidade de estar presentes (Jay B. Barney/William S. Hesterly, 2011, p. 29)." Essas ameaças são: 


\subsubsection{Ameaça de entrada}

"A primeira ameaça ambiental identificada na estrutura de cinco forças é a de nova entrada. Novos entrantes são empresas que iniciaram operações recentemente em um setor ou que ameaçam começar operações em breve (Jay B. Barney/William S. Hesterly, 2011, p. 31)."

Nesse sentido, empresa que podem chegar ameaçando a situação do CBLOL seria, por exemplo, a Blizzard, que também possui um jogo forte no mercado e com o sistema de franquias estabelecido nos Estados Unidos, o Overwatch.

"A ameaça de entrada depende do custo de entrada, e este, por sua vez, depende da existência e da "altura" das barreiras à entrada. Barreiras à entrada são atributos da estrutura de um setor que aumentam o custo de entrada. Quanto maior é esse custo, mais altas são as barreiras (Jay B. Barney/William S. Hesterly, 2011, p. 29)."

Em um mercado aonde existe barreiras de entrada muito elevadas, potenciais competidores terão poucas chances de ingressarem, devido ao risco de custos e de competir com uma empresa forte e já estabelecida. Voltando ao exemplo, o quão vantajoso seria para a Blizzard entrar em um mercado já estabelecido pela Riot Games?

\subsubsection{Ameaça de rivalidade}

"Uma segunda ameaça ambiental da estrutura de cinco forças é a rivalidade - a intensidade da competição entre os concorrentes diretos de uma empresa. A rivalidade ameaça empresas, reduzindo seus lucros econômicos (Jay B. Barney/William S. Hesterly, 2011, p. 35)."

Um exemplo de rival no mercado é a Valve, dona do Counter Strike, jogo bastante antigo. Os dois tem direitos adquiridos pelo SporTV para transmitir os jogos de cada modalidade, evidenciando que as duas possuem as maiores audiências no Brasil.

\subsubsection{Ameaça de substituto}

"Uma terceira ameaça ambiental da estrutura de cinco forças são os substitutos. Os produtos ou serviços oferecidos por rivais de uma empresa atendem praticamente às mesmas necessidades do cliente, da mesma maneira 
que os produtos ou serviços oferecidos pela própria empresa (Jay B. Barney/William S. Hesterly, 2011, p. 36)."

As empresas precisam ficar atentas ao mercado para que novos produtos ou serviços não reduzam seus lucros ou a façam falir. Dessa forma, no mercado de videogame, o que faz as pessoas consumirem mais, seja assistir ou jogarem, é a moda, com isso há sempre novas ameaças de produtos que possam substituir os que já existem, migrando jogadores de um para o outro.

\subsubsection{Ameaça de fornecedores}

"A quarta ameaça ambiental da estrutura de cinco forças são os fornecedores. Eles disponibilizam para as empresas uma ampla variedade de matérias primas, mão de obra e outros bens essenciais. Podem ameaçar o desempenho de empresas em um setor aumentando o preço ou reduzindo a qualidade de seus suprimentos (Jay B. Barney/William S. Hesterly, 2011, p. 36)."

Assim, os times que estão presentes na liga são fundamentais para que ela aconteça com qualidade, já que eles contratam jogadores, atraem patrocínios e com isso, um maior público. Manter essa relação boa, além de ter equipes funcionando de maneira plena e saudável, faz com que o CBLOL fique cada vez mais atrativo.

\subsubsection{Ameaça de compradores}

"Os compradores são a última ameaça ambiental da estrutura de cinco forças. Eles adquirem os produtos ou serviços de uma empresa. Enquanto os fornecedores agem para aumentar os custos de uma empresa, os compradores agem para reduzir o lucro dela (Jay B. Barney/William S. Hesterly, 2011, p. 37)."

Dessa maneira, é fundamental que a empresa venda para mais de uma pessoa ou empresa, no caso do CBLOL é preciso ter mais de um patrocinador, recebendo receita em troca de divulgação de uma marca, além de vender seus direitos de imagem para diferentes redes de distribuição, tanto na internet com plataformas de streaming com o Youtube e o Twitch, como em canais de televisão, a exemplo do SporTV. Com o modelo de franquias instaurado em ligas externas, a Riot Games consegue também vender as vagas da sua liga para organizações, tendo assim mais uma fonte de receita.

Analisando o mercado com essas cinco etapas, as empresas conseguem mapeá-lo e saber caracterizar o nível geral de ameaça no setor, além de poder 
prever o nível-médio de desempenho de organizações presentes em um determinado segmento.

\subsection{Avaliação das capacidades internas de uma empresa}

O modelo das cinco forças apresentado anteriormente diz respeito à análise do ambiente externo onde uma empresa está inserida. Já o modelo VRIO é baseado na capacidade interna de uma organização em criar vantagem competitiva, desenvolvendo um conjunto de ferramentas para analisar os diferentes recursos e capacidades de uma organização, assim será possível identificar as forças e fraquezas que ela possui.

Definindo o que são recursos e capacidades, "recursos são definidos como ativos tangíveis e intangíveis que a empresa controla e que podem ser usados para criar e implementar estratégias (Jay B. Barney/William S. Hesterly, 2011, p. 58)."

"Capacidades formam um subconjunto dos recursos de uma empresa e são definidos como ativos tangíveis e intangíveis que permitem à empresa aproveitar por completo outros recursos que controla (Jay B. Barney/William S. Hesterly, 2011, p. 58)."

Um exemplo de recursos da Riot Games é o jogo League of Legends, o estúdio que ela possui para a realização do CBLOL, esses são ativos tangíveis. Já a marca que ela possui no mercado de Esports é um ativo intangível. As capacidades permitem que uma empresa utilize de seus recursos para criar e implementar estratégias, um exemplo disso são as pessoas que trabalham na Riot iniciando conversas para implementar o modelo de franquia no CBLOL.

\subsubsection{O modelo VRIO}

"Munido da VBR, é possível desenvolver um conjunto de ferramentas para analisar os diferentes recursos e as diferentes capacidades que uma empresa pode possuir, bem como o potencial de cada um deles para gerar vantagens competitivas. Dessa forma, será possível identificar as forças e as fraquezas internas de uma empresa. A principal ferramenta para conduzir essa análise interna é chamada de modelo VRIO. O modelo VRIO diz respeito a quatro questões que devem ser consideradas sobre um recurso ou uma capacidade para determinar seu potencial competitivo: as questões de valor, da 
raridade, da imitabilidade e da organização (Jay B. Barney/William S. Hesterly, 2011, p. 61)."

Com uma análise realizada com base nesse modelo, é possível identificar as forças e fraquezas da Riot Games, através de fatores, como valor, raridade, imitabilidade e organizacional, fazendo com que utilize recursos e capacidades para criar vantagens competitivas em relação ao mercado e seus competidores.

\subsubsection{A questão do valor}

"A questão do valor é: "Os recursos e as capacidades permitem que uma empresa explore uma oportunidade externa ou neutralize uma ameaça externa?" Se uma empresa responder 'sim' a essa pergunta, então seus recursos e suas capacidades são valiosos e podem ser considerados como forças da empresa. Se uma empresa responder 'não', quer dizer que seus recursos e suas capacidades são fraquezas (Jay B. Barney/William S. Hesterly, 2011, p. 61)."

Os recursos e capacidades são valiosos na medida em que permitem uma empresa melhorar sua posição competitiva, podendo ser os mais simples possíveis ou mais elaborados, dependendo, alguns mesmos recursos em um mercado podem ser fortes e em outros podem ser fracos.

\subsubsection{A questão de raridade}

"Se determinado recurso ou capacidade é controlado ou controlada por muitos concorrentes, então tal recurso dificilmente será uma fonte de vantagem competitiva para qualquer um deles. Em vez disso, recursos e capacidades valiosos, mas comuns (isto é, não raros), são fontes de paridade competitiva. Apenas quando um recurso não é controlado por inúmeros concorrentes é que tenderá a se tornar uma fonte de vantagem competitiva. Essas observações levam à questão da raridade: "Quantas empresas concorrentes já possuem determinados recursos e determinadas capacidades valiosos? (Jay B. Barney/William S. Hesterly, 2011, p. 61)."

A ideia central da questão de raridade é entender o valor dos recursos e capacidades de uma empresa, se ela possuir um ótimo recurso, que a ajude a realizar boa parte de suas atividades, sendo de suma importância, mas que outras empresas também possuem, este recurso não é raro. Porém, se for algo 
que nenhuma ou poucas organizações têm acesso, se caracteriza como algo raro.

\subsubsection{A questão da imitabilidade}

"Recursos organizacionais raros e valiosos só podem ser fontes de vantagem competitiva sustentável se as empresas que não os possuem enfrentam uma desvantagem de custo para obtê-los ou desenvolvê-los, comparadas às empresas que já os possuem. Esses tipos de recursos são imperfeitamente imitáveis. Essas observações levam à questão da imitabilidade: "As empresas que não possuem um recurso ou uma capacidade enfrentam uma desvantagem de custo para obtê-lo ou desenvolvê-lo em relação às empresas que já o possuem?" (Jay B. Barney/William S. Hesterly, 2011, p. 67)."

Organizações que detém de recursos raros e valiosos conseguem ser inovadoras estrategicamente no mercado, uma vez que é possível estabelecer estratégicas que outras não conseguem devido a esses recursos diferenciados, criando uma vantagem competitiva, podendo até chegar a situações em que outras organizações enfrentem desvantagens de custo para imitar, criando uma vantagem competitiva sustentável, que não pode ser eliminada pela competição por meio de imitação estratégica.

\subsubsection{A questão da organização}

"O potencial de uma empresa para vantagem competitiva depende do valor, da raridade e da imitabilidade de seus recursos e suas capacidades. No entanto, para aproveitar esse potencial ao máximo, uma empresa deve estar organizada para explorar seus recursos e suas capacidades. Essas observações levam à questão da organização: "A empresa está organizada para explorar ao máximo o potencial competitivo de seus recursos e suas capacidades?" (Jay B. Barney/William S. Hesterly, 2011, p. 61)."

Os sistemas implementados dentro da organização fazem com que ela use de maneira adequada seus recursos e capacidades para criar vantagem competitiva, como ela funciona, isso inclui como funciona sua estrutura de reporte, sistemas de controle gerencial e políticas de remuneração. Um organograma bem planejado faz com que as pessoas saibam a quem se reportar e estipula certo controle estrutural. Além disso, é fundamental garantir que os gerentes estejam se comportando de maneira adequada referente às estratégias 
da empresa, com um sistema de controle gerencial. E por fim, como os colaboradores são remunerados, incentivando-os a seguir normas e procedimento, criando um clima harmônico na organização. 


\section{Metodologia}

\subsection{Método de pesquisa}

A pesquisa se classifica como descritiva, tendo como apoio dados publicados por imprensa do Brasil e internacional, além de pesquisas de consultorias especializadas no meio de Esports, com ênfase na modalidade sobre League of Legends. Com um número de 100 milhões de jogadores no mundo, chegando a um pico de 8 milhões jogando ao mesmo tempo, a desenvolvedora Riot Games adotou o modelo de franquia em diversos países.

\subsection{Universo e amostra}

A pesquisa foi realizada com diferentes pessoas que atuam no meio, tanto como consumidoras de League of Legends a respeito de jogar e assistir aos campeonatos, quanto a outras que trabalham no meio, como jogadores e criadores de conteúdo. O questionário busca entender o mercado do CBLOL afim de criar conclusões se o modelo de franquias seria benéfico para a liga. Os entrevistados foram:

- Gustavo "GSTV" Cima - comentarista de League of Legends

- Germano "Hunbaut" Pereira - espectador do CBLOL

- Rodrigo "RV17" Veras - espectador do CBLOL

- Emerson "BocaJR" Alencar - jogador profissional de League of Legends

- Marcelo Mello - jogador profissional de League of Legends

- Vinicius - Dono da liga amadora Empolgou CBLOL

\subsection{Coletas de dados}

Os entrevistados foram escolhidos a fim de obter uma percepção maior a respeito do mercado do Circuito Brasileiro de League of Legends, coletando diferentes opiniões de pessoas que atuam em vários segmentos no setor, desde consumidores até quem exerce ofício. 
As pessoas foram selecionadas de maneira que fossem mais facilmente contatadas pelo entrevistador, tendo em vista que há poucas pessoas qualificadas que trabalham no meio para realizar uma pesquisa com cunho voltado a gestão. Foram escolhidos os que possuíam experiência e tempo no setor para dados e opiniões mais consolidadas.

\subsection{Procedimento e tratamento de dados}

Os dados foram obtidos através de entrevistas individuais, realizadas de forma presencial, por e-mail ou por via internet através de programas que possibilitasse transmissão de áudio, com gravação de áudio sempre que possível, sempre com autorização de quem estava sendo entrevistado.

Assim que todas as entrevistas foram feitas, os dados foram organizados em uma planilha postas lado a lado, analisando qualitativamente o conteúdo, a fim de encontrar associações entre as respostas, utilizando as teorias de cinco forças de Porter e o modelo VRIO para que consiga conclusões relevantes para o estudo.

\subsection{Limitações do estudo}

As entrevistas aconteceram com pessoas que atuam no meio, tendo uma opinião enviesada a respeito, podendo ter uma visão turva da real situação presente no setor. Outra limitação seria a influência que o entrevistador possa ter sobre os entrevistados, mostrando sua parcialidade, induzindo os entrevistados a responder o que quer ouvir. Por fim, a análise dos dados por ser influenciada, já que quem analisa tem uma opinião formada, influenciando nos resultados encontrados. 


\section{Apresentação e análises dos resultados}

\subsection{O Circuito Brasileiro de League of Legends}

Baseado nas pesquisas realizadas pelas pessoas que estão inseridas no meio, o Circuito Brasileiro de League of Legends, vulgo CBLOL, representa tanto as realizações profissionais, tanto um meio de entretenimento prazeroso para quem assiste. Para os jogadores e organizadores do campeonato, o fator de trabalhar com o que era uma distração acaba sendo uma conquista, algo que descrevem como estarem vivendo um sonho, de poder ganhar salário e tendo um emprego relacionado a videogame.

"Cara a importância do CBLOL é gigantescamente gigantesca, por que ele me dá o meu trabalho e faz com que eu viva com o que eu sonho além de mostrar para todo mundo o que é o lol competitivo."

"E a do Circuito Desafiante tem a mesma importância que é de trazer pessoas novas ou não para o nosso cenário dando oportunidades a todos, porque no CBLOL testar alguém de soloq é bem difícil, já no circuito desafiante não tanto." (Emerson "BocaJR" Alencar - jogador profissional de League of Legends).

Também é citado o Circuito Desafiante, torneio de acesso a elite de League of Legends brasileiro, nesse torneio é onde aparecem novas equipes no cenário, além de novos jogadores, podendo se tornar estrelas, sendo importantes na conquista de títulos. Dessa forma, os dois torneios atuam de forma conjunta para sempre estarem aumentando o nível dos jogadores, em questão de habilidade, e também fazendo com que as equipes tenham uma postura mais profissional, gerindo de maneira adequada os negócios.

"Competitivamente falando a importância do CBLOL é dar base para uma região tão grande como o Brasil em crescer e formar novos talentos. O Circuito Desafiante dando ainda mais base ao CBLOL e seguindo para o "Tier 3" também, tudo isso molda um ecossistema que permite cada vez mais gente ter um 
trabalho em torno dos esports." (Gustavo "gstv" Cima comentarista de League of Legends).

A respeito dos consumidores do CBLOL, eles pensam no torneio como um meio de se entreter, assistindo um programa que desperta curiosidade, seja no âmbito de qualidade dos jogos, como um nível de competitividade alta, deixando o jogo emocionante do início ao fim, tanto em questão de aprendizado, pois qualquer pessoa pode observar o que os profissionais realizam e imitá-los em uma partida de League of Legends.

"Assisto por entretenimento, porque gosto de assistir os jogos e também acabo aprendendo com as jogadas, assistindo as partidas. Circuito Desafiante eu só assisti as finais e semifinais por causa da Red Canids, mas eu não curto não." (Rodrigo "RV17" Veras -expectador de League of Legends).

"O CBLOL é importante porque como eu gosto do jogo eu quero me informar sobre ele e também gosto de me entreter com o campeonato. Não acho o Circuito Desafiante chama muito atenção, acho que o modo de fazer deles não é bom, a estrutura não agrada muito, dão menos valor ao campeonato, parece que os jogadores não se importam muito." (Germano "Hunbaut" Pereira - Espectador de League of Legends)

Baseado nessas duas opiniões, é possível perceber que a segunda divisão não agrada os espectadores como a primeira divisão, isso se deve graças a estrutura que é diferente em relação a liga principal. O motivo é que uma empresa terceirizada que cuida da administração do Circuito Desafiante, assim o modelo é diferente, fazendo com que os consumidores estranhem. Porém, recentemente, foi anunciado no site oficial de esports da Riot Brasil, que a partir de 2020 a desenvolvedora voltará a assumir a produção do torneio, prometendo uma maior integração com o CBLOL, com novos formatos e formas de acompanhar a transmissão, mirando uma melhora na qualidade.

\section{2. $O$ modelo de franquias no CBLOL}

Para que a Riot Games inicie o modelo de franquias no CBLOL é necessário um grande porte de capital pelas equipes para adquirirem uma vaga na liga, sendo assim um alto investimento, logo também é necessário ter uma 
boa estrutura para os jogadores e uma gestão a altura para sustentar o negócio. Outra consequência é a extinção do Circuito Desafiante, já que nenhuma equipe será mais rebaixada, virando um outro torneio, onde cada equipe do CBLOL teria uma vaga, tendo um time $B$, usando como teste para descobrir novos jogadores e também como uma liga alternativa, procurando ser o campeão.

Os entrevistadores acreditam que esse modelo possa ser benéfico para o cenário, já que a estabilidade faz com que as organizações invistam e arrisquem mais em novas promessas, além de tentarem introduzir novas estratégias no jogo, ficando com menos medo de errar, e com mais coragem de tentar inovações. Além de maiores investimentos e dinheiro entrando para as equipes, com patrocínios de peso como nos esportes tradicionais.

"Eu creio que é mais positivo do ponto de vista comercial. Para algumas equipes é algo bom, porque vai dar maior estabilidade e permitir maior investimento sem riscos de ser rebaixado. A estabilidade de estar na elite ainda atrairá mais patrocinadores. Isso ainda permitiria uma rotação maior dos jogadores, já que arriscar um jogo com uma revelação não se torna não oneroso, em caso de derrota. Ainda tem a questão que com a liga em franquias, teríamos a liga academy, com todas equipes sendo obrigadas a investir na base também." (Vinicius Dono da liga amadora Empolgou CBLOL)

"Pra mim, a franquia tem no total muito mais pontos positivos do que negativos, o maior ponto positivo é o dinheiro mesmo, acho que o cenário brasileiro poderia evoluir em muitas coisas, mas se evoluir em relação ao dinheiro, conseguimos avançar muito no cenário internacional." (Emerson "BocaJR" Alencar - jogador profissional de League of Legends)

Entretanto, há também os pontos negativos da consequência da implantação do modelo, podendo deixar a liga menos atrativa em questão de visualizações e de investimentos. Pontos levantados pelos entrevistados são de as equipes se manterem estagnadas, devido à estabilidade que o modelo proporciona, já que nenhuma equipe mais corre o risco de sair do CBLOL e também o fato do grande investimento inicial, sendo uma barreira para equipes pequenas e eventuais novas, ou até fazer com que equipes existentes no mercado não conseguirem ingressar adquirindo uma vaga. 
"O primeiro é que nem todas as equipes que estão na elite hoje teriam aporte financeiro para comprar uma vaga. Isso faria com que equipes tradicionais pudessem ser excluídas do cenario além de restringir muito a entrada de equipes menores, $q$ dependeriam não só de desempenho, mas de atrair patrocinadores se quiser comprar uma vaga. Outro problema é que a competitividade pode ficar comprometida. Sem o risco de rebaixamento as equipes de meio de tabela podem se acomodar, aceitando que não vão mais se classificar e tornando o nível do torneio mais baixo." (Vinicius - Dono da liga amadora Empolgou CBLOL)

"O negativo seria que os time podem não ter dinheiro suficiente para manter a estrutura adequada ou não ter investimento para comprar uma vaga." (Germano "Hunbaut" Pereira - Expectador de League of Legends)

Essas opiniões foram baseadas em alguns fatos observados ao longo dos anos no meio de Esports brasileiro e de ideias dos entrevistados. A seguir, serão realizadas análises do meio externo e interno da Riot Games, a fim de saber se ela possui ou não vantagem competitiva em relação aos concorrentes para que esse modelo seja uma escolha viável de forma financeira.

\subsection{Análise ambiental do CBLOL}

Mapeando o mercado tendo como base o CBLOL, é possível identificar o ambiente que se encontra, analisando as cinco ameaças mais comuns que as empresas enfrentam, procurando saber quais apresentam maior e menor força, para que seja criada uma vantagem competitiva. Dessa forma, será possível entender se a liga brasileira, implantando esse modelo, terá vantagens relacionados às outras presentes no país.

\subsubsection{Ameaça de novos entrantes}

No mercado internacional, a quantidade de jogos que são lançados anualmente é gigantesca, há diversas desenvolvedoras espalhadas através do globo, desde as maiores e gigantes do setor, como a Blizzard e a EA Sports, até pequenos desenvolvedores. Esses artigos de entretenimento estão presentes 
em diferentes locais, como por exemplo, máquinas feitas especialmente para que o usuário consuma os jogos, que são os consoles. Outro exemplo são os computadores, presentes em grande parte da população. E agora outro aparelho que vem ganhando força e que está presente basicamente na casa de todo brasileiro, são os celulares, jogos como Clash Royale, mais competitivos, chegando ao viciante Candy Crush, praticamente toda pessoa tem acesso a algum tipo de jogo.

Entretanto, não é todo jogo que ameaça o CBLOL, pois para competir com o League of Legends, ele precisa apresentar características que o façam ser competitivo, ter um torneio baseado nele. Alguns "games" são apenas de história, apresentam início e fim, e após completá-lo não há mais nada o que fazer. Os Esports são caracterizados por jogos que apresentam competição, um objetivo em pelo menos uma pessoa contra a outra, fazendo uma se consagrar vencedora. Dessa forma, alguns jogos são produzidos e, ao longo dos 10 anos de existência do League of Legends, poucos jogos o ameaçaram, criando uma liga e deixando o CBLOL para traz.

Uma característica dos games é que as pessoas o consomem baseado na moda do momento, quando ele é lançado, normalmente a desenvolvedora fez um marketing, promovendo-o e fazendo a comunidade toda comentar bastante antes do lançamento, criando uma expectativa alta. Porém, ao longo do tempo, quando ele se consagra conhecido, as pessoas vão enjoando e procurando outros para jogar. Esse fato parece se aplicar pouco ao League of Legends, e consequentemente se aplicando ao CBLOL. Mesmo com 10 anos de existência, o LoL apresenta números expressivos, baseado no que a Riot Games informou, são 100 milhões de jogadores mensais, batendo o pico de 8 milhões em um dia. Dados comparados com uma plataforma de venda de jogos, a Steam, seus 10 games mais famosos, somados, apresentam pico de jogadores de 2,3 milhões por dia, nesse quesito o League of Legends ganha com folga do seu principal concorrente, o Dota 2, este título está presente nos 10 games mais populares da Steam. É muito difícil algum jogo aparecer para desbancar o reinado que o LoL apresenta até agora e isso fica claro na opinião dos entrevistados.

"Eu creio que justamente pelo jogo já ter esse tempinho que é vantajoso. Se falássemos em 2015 desse assunto, teríamos sérias dúvidas se valeria a pena. O cenário era instável, o jogo ainda era recente no país e colocar esse dinheiro seria um alto risco. “ 
"Agora em 2019 com o Brasil quebrando recordes de audiência, com mais eventos presenciais, além de grandes marcas (Gillete/Dell/Red Bull) patrocinando o campeonato, para as equipes a margem de segurança é maior."

"Vale lembrar que muitas equipes possuem patrocínio pesado atualmente como Pain (Coca-Cola, BMW), Kabum ( $A$ própria loja), CnB (Que tem por sócio o Ronaldo "Fenômeno"), Flamengo (Banco Bs2)... Então seria mais fácil para elas."

"Vale lembrar que o lol está aí e sempre falam que outro jogo iria ultrapassa-lo, como foi com Overwatch, Apex, Fortnite... E por um momento até passaram. Mas é apenas o famoso "hype", ou seja, ficou a frente no lançamento. Mas qd estabiliza acaba ficando para trás." (Vinicius - Dono da liga amadora Empolgou CBLOL)

Perguntado a respeito de investir em franquias, mesmo o LoL apresentando muitos anos de vida, Emerson acredita que isso é uma força, mostrando que por ele ser antigo, faz com que se cria uma estabilidade nos consumidores, combatendo os novos entrantes e também concorrentes.

"Com toda a certeza, a Riot games sempre mostrou ser eficaz em mostrar evolução em todas as áreas, em todo o mundo literalmente os números apenas sobem, então não tem um porquê de cair com isso não tem um porquê de alguém não comprar uma vaga. Principalmente agora após o anuncio de tantos jogos começando a serem desenvolvidos, isso só mostra o quanto a Riot está empenhada em alavancar o nome deles." (Emerson "BocaJR" Alencar - jogador profissional de League of Legends)

A ameaça de novos entrantes é alta em questão de facilidade, as desenvolvedoras conseguem criar um jogo de Esport de maneira tranquila, porém estabelecê-los no mercado com uma liga forte é o desafio. O Overwatch chegou com uma expectativa muito alta, sendo pico de audiência em sites de streaming de jogos. Fora do Brasil o jogo possui uma liga franqueada, com grandes números de audiência, porém em terras brasileiras ele não conseguiu se consolidar criando uma liga. Outro exemplo recente foi o Apex Legends, lançado em fevereiro de 2019, o game de tiro onde o jogador precisa sobreviver em um ambiente com outros "players", conseguiu ter altos picos nas plataformas de streaming, porém não conseguiu manter a crescente, caindo no quesito 
visualizações e jogadores, não conseguindo manter uma liga. Dessa forma, a ameaça de novos entrante para o CBLOL é alta, porém a liga possui muito Market share no mercado e muitas pessoas aos quais assistem, porém há sempre a possibilidade de um novo jogo com uma liga mais atrativa entrar no mercado.

\subsubsection{Ameaça de rivalidade}

Como visto anteriormente, o setor de jogos é aquecido, com o lançamento de diversos títulos ao decorrer do ano, com isso, vários já estão no mercado a muito tempo, estabelecidos e sendo um concorrente para o League of Legends e para o CBLOL. Um exemplo é o jogo chamado de Rainbow Six Siege, lançado em dezembro de 2015 pela empresa Ubisoft Montreal, muito popular no Brasil, possui uma liga competitiva parecida com o CBLOL, onde há fase de grupo onde os competidores se enfrentam, até chegar nas eliminatórias com 2 times na final. Dos 8 times presentes no campeonato, 4 possuem um time na modalidade de LoL, sendo 2 no CBLOL e 2 na liga americana.

As duas ligas são concorrentes, onde disputam gosto dos consumidores e também organizações para disputar os campeonatos. Porém, algumas conseguem atuar nos dois torneios, outras escolhem apenas um. Olhando os números apresentados, o CBLOL está bem à frente em questão de audiência, segundo informações da própria empresa desenvolvedora, Riot Games, a final do CBLOL de 2019 realizada na Jeunesse Arena teve um pico de 316 mil espectadores simultâneos assistindo à partida entre Flamengo contra INTZ. Já Ubisoft não divulgou números sobre, mas em um torneio de nível semelhante ao campeonato brasileiro de Rainbow Six, a Pro League teve um pico de 31.786 pessoas, assistindo o clássico entre Team Liquid e Faze Clan. Questionado a respeito de outra liga tomar a importância do CBLOL, os entrevistados acreditam que possa acontecer, mas no futuro.

"Eu sinceramente acho muito difícil, mas sempre pode acontecer, pensei que quando o Overwatch explodiu no começo ia dar certo, mas não sei muito bem o que aconteceu que não foi pra frente, acho que os outros jogos tem alguns pontos melhores que a Riot, como o Dota dar muito mais dinheiro em premiação do que a Riot, mas no completo o LoL sempre é melhor, então é muito difícil isso acontecer." (Emerson "BocaJR" Alencar - jogador profissional de League of Legends). 
"É difícil. Não se trata apenas de divulgação, premiação e promoção. A popularidade de um Esport é diretamente proporcional ao tamanho do público do jogo. Nisso o LoL ganha com sobras. É o jogo mais popular há muito tempo. Além disso tem o fator de quão é divertido assistir um jogo em primeira ou terceira pessoa."

"Dos jogos em evidência, o LoL é um dos poucos com visualização em terceira pessoa. Ou seja, você vê como campo e o que está acontecendo como um espectador. Isso se assemelha muito como vemos um jogo de esporte tradicional."

"Outros jogos com ligas como cs:Go, free fire, Overwatch tem a visão em primeira pessoa a maior parte do tempo. O que torna difícil de acompanhar tudo de uma vez."

"Além da popularidade e perspectiva, ainda há a questão de estabilidade das equipes. Um fã de Cblol saberá dizer as oito equipes da primeira divisão de memória. Isso nem sempre acontecerá ao perguntar sobre quais equipes que estiveram no último major de CS:Go." (Vinicius - Dono da liga amadora Empolgou CBLOL)

Outra questão a ser observada a respeito da rivalidade entre as ligas é em questão de patrocínio, o CBLOL hoje conta com parceiros como a Gillette e a Dell, gigantes no setor que atuam. Já no BR6, o brasileiro de Rainbow Six Siege, a patrocinadora é a Lenovo. Cada vez mais as marcas estão vendo a audiência que essas ligas apresentam como relevante, tentando associar a marca ao público, para ganhar espaço no mercado. Isso acontece nas organizações que disputam as competições, por exemplo a Havan, empresa varejista, investiu em um time que leva o seu nome no League of Legends.

O setor possui poucas ligas, como as duas citadas anteriormente, e mais o Circuito Brasileiro de Counter Strike, e a concorrência acaba ameaçando pouco o reinado do CBLOL, pois em questão de visualizações e mídia ele ganha disparadamente, mostrando maior organização, estabilidade e entretenimento, fazendo com que a ameaça de rivalidade seja baixa.

\subsubsection{Ameaça de substitutos}

Outra ameaça que podem aparecer são de outras empresas oferecerem produtos ou serviços que atendam de maneira quase igual às necessidades dos 
clientes. Dessa forma, as pessoas podem para de assistir o CBLOL para ver outro tipo de jogo, jogar outro tipo de jogo, ler a respeito na internet ou por revistas, as possibilidades são extensas. Entretanto, pensando nisso, a Riot Games mantém o jogo sempre atualizado, para que os jogadores não entrem em um looping onde cada jogo pareça repetitivo. De tempos em tempos, a desenvolvedora balanceia o League of Legends, deixando alguns campeões mais fortes que outros, mexendo no mapa, em objetivos dentro do jogo, fazendo ele mudar e se torne mais dinâmico.

"Acredito que toda a apresentação de 10 anos do League mostram diversos caminhos pelos quais a Riot planeja evoluir para manter o interesse nos produtos. No fim, é todo um meio inexplorado, já que são poucos jogos que tem uma player base desse tamanho há tanto tempo (me arrisco a dizer que nenhum na história)." (Gustavo "gstv" Cima - comentarista de League of Legends).

"Primeiro que o jogo é de graça, apesar de poder comprar cosméticos no jogo, isso não muda em jogabilidade. Eles mudam o jogo constantemente, isso é bom que dá uma variada, não fica algo massante, toda partida pode ser diferente, não é que nem Call of Duty que você joga sempre a mesma coisa e acaba enjoando." (Rodrigo "RV17" Veras -expectador de League of Legends).

Dessa forma, existe uma ameaça grande, já que o consumidor pode mudar de hábito e começar a consumir outras opções de entretenimento, mesmo com a Riot trabalhando sempre em melhorias e pensando em formas de fidelizar ainda mais quem joga e quem assiste. Essa situação também ameaça quem patrocina e investe no jogo, pois se a audiência baixar demais, devido a algum produto substituto, as empresas podem parar de injetar dinheiro, pois podem avaliar que o CBLOL não estaria dando mais o retorno esperado, ou seja, pode ocasionar um efeito em cascata.

\subsubsection{Ameaça de compradores}

Os compradores são aqueles que agem para diminuir o lucro que a empresa almeja, são os clientes, os que consomem os produtos e serviços. Neste caso, o CBLOL possui dois grupos principais, os expectadores que 
assistem as partidas e as organizações que possuem times para competirem. Começando com os espectadores, são responsáveis pela audiência do CBLOL, quanto maior, mais visibilidade e importância a liga ganha, atraindo investidores, patrocínios e novos interesses de organizações, dessa forma são determinantes para o sucesso do negócio. Com dados disponibilizados pela Riot, houve um crescimento de mais de $40 \%$ de espectadores da final em relação ao ano passado, 2018, mostrando maior engajamento dos clientes. A desenvolvedora precisa ficar atenta às suas ações para sempre deixar os clientes interessados em assistir aos jogos, isso tem acontecido com maiores ações de marketing na liga, como programas que são exibidos durante a semana para maior frequência de conteúdo, um focado na liga do Brasil e outro nas diversas espalhadas pelo mundo. Melhorias e modificações são feitas no League of Legends para que dê mais dinâmica e possibilidades no jogo, fazendo com que sempre tenha algo de novo, despertando interesse do público.

Dados da consultoria especialista do cenários de Esports, Newzoo, afirma que em 2018 haviam de 7.6 milhões de pessoas entusiastas em Esports no Brasil, ou seja, pessoas que assistem conteúdo relacionado a Esports mais de uma vez por mês, sendo o terceiro maior mercado do mundo, perdendo apenas para China e Estados Unidos. No geral, são 18,3 milhões de pessoas no Brasil que assistem Esports, tendo previsão para 2021 de serem 27,9 milhões, evidenciando o poder do setor. Dessa maneira, a Riot Games precisa manter os clientes interessados, fidelizando os existentes e capturando novos, pois o setor apresenta bastante competição, com bastante jogos sendo lançados anualmente e os já existentes criando novidades.

"O marketing é muito poderoso, com trailers que atraem as pessoas, músicas feitas para o jogo, despertando sempre a vontade de jogar. Também em relação aos campeonatos, conseguem deixar todos animados com trailers, transmissões com jogos bem disputados." (Germano "Hunbaut" Pereira - Espectador de League of Legends)

Uma situação que pode ocorrer no novo modelo de franquias é um time consolidado no mercado não conseguir comprar a vaga para poder atuar no novo CBLOL, seja por não ter capital suficiente para investir ou por outras organizações terem dado mais dinheiro ou outra razão qualquer. O exemplo apresentado pelo torcedor do Flamengo, Rodrigo, diz respeito a perda de 
interesse das pessoas na liga se o time a qual elas torcem não conseguir a vaga. Nessa situação os dois compradores do CBLOL se unem, já que, se o Flamengo não conseguir uma vaga no novo modelo, a Riot perderá uma grande marca presente no seu torneio, afastando outras empresa patrocinadoras do time, como o Banco BS2, dentre outros, também podendo influenciar no público do CBLOL no quesito espectadores, uma vez que há pessoas que só assistem jogos do seu próprio time.

"Os times vão ficar maiores, os times tendo o principais e a academy, os times vão melhorar, com mais jogadores na organização, e torneios. Com menos time a competição fica mais disputado. O torcedor que vê o time virando uma franquia é muito bom, porque ele continua torcendo, já o torcedor de uma equipe pequena, por exemplo, Progaming, se ela não conseguir a vaga capaz deles perderem o interesse no CBLOL." (Rodrigo "RV17" Veras -expectador de League of Legends).

"Sim, eu torço para o Flamengo. Eu só paro pra assistir o CBLOL para assistir os jogos do Flamengo, se eu não tiver nada para fazer eu assisto os outros jogos, mas a prioridade é assistir o Flamengo." (Rodrigo "RV17" Veras -expectador de League of Legends).

Assim, as organizações também são importantes para a saúde da liga, e tem relação direta com os espectadores, quanto maior audiência, maior interesse das marcas, pois querem anunciar para um maior número de pessoas que assistem todo fim de semana o campeonato, ou seja, estão em procura de alcance e frequência. Exemplos de empresas são a Vivo e a Kalunga, que compraram o naming right das respectivas equipes que levam o nome de Vivo Fibra Keyd Stars e Red Canids Kalunga, além de empresas varejistas que são donas de times, como o caso do Kabum, que possui dois títulos de CBLOL, e a Havan, recem chegada ao cenário. Se o número de espectadores for caindo, algumas empresas podem deixar de investir no CBLOL, vendo que o retorno não será mais satisfatório, podendo até migrar para outra liga que esteja em alta no momento. Dessa maneira, a força de compradores é alta, pois eles são a alma do negócio. 


\subsubsection{Ameaças de fornecedores}

A força de fornecedores diz respeito a empresas ou pessoas que disponibilizam matérias-primas, produtos, mão de obra e outros bens essenciais para outra organização a fim de suprir as necessidades, fazendo com que realize suas atividades. No caso do CBLOL, é de suma importância os computadores onde acontecem as partidas, precisam ser de qualidade para que os atletas possam ter uma experiência adequada, sem ocorrer travamentos ou outros problemas técnicos. Dessa forma, o público também consegue assistir um jogo de qualidade, com imagem limpa e fluidez. Outro ponto crucial são as transmissões, é preciso um estúdio bem elaborado, com câmeras para transmitir imagens e vídeo em alta definição, melhorando a experiência do público. Uma internet estável também é necessária, já que grande parte do conteúdo é disponibilizado na internet, assim qualquer problema com a rede pode prejudicar a transmissão.

Em questão da qualidade dos computadores, hoje no Brasil há algumas empresas que fornecem esses hardwares apropriados para um jogo de alto nível, porém não são muitas. A partir de janeiro de 2019, a Riot Games firmou um patrocínio com a Dell, onde a empresa divulga sua marca através de propaganda entre as partidas e ativação de marca sobre o League of Legends. Entretanto, não é somente de divulgação que é a relação entre as duas, a organização de tecnologia também disponibiliza computadores de alta performance, além de monitores mais recentes do mercado, tudo para maior conforto dos atletas e divulgação para as pessoas que assistem.

"Os Esports são uma prioridade de investimentos para a Dell Gaming no Brasil. A parceria com a Riot em League of Legends gera uma associação da marca e dos produtos ao alto desempenho e precisão que são essenciais para a disputa das partidas no CBLoL", justifica Vinicius Lima, gerente de marketing da divisão Dell Gaming no Brasil. "A presença no CBLoL também permitirá que os fãs do cenário conheçam as principais tecnologias desenvolvidas pela Dell em um ambiente de altíssima competitividade, em que cada milissegundo conta", explica. (Grandes Nomes da Propaganda, 2019).

Outras situações que a Riot encontra são as de transmitir o evento e a montagem do estúdio, todas essas duas requer uma qualidade de tecnologia alta, e no Brasil acaba que existem poucos fornecedores que provem a qualidade esperada, assim a empresa está em um setor dominado por um número pequeno de empresas, que vendem produtos altamente diferenciados, 
caracterizando um ambiente com uma ameaça alta, já que esses fornecedores acabam tendo um poder de negociação alto, já que não há a possibilidade de procurar outro com as mesmas qualidades.

\subsection{Análise VRIO do CBLOL}

Essa análise tem como objetivo analisar os recursos que a empresa apresenta, de forma que seus potenciais possam criar vantagens competitivas. Caracteriza-se de uma análise de ambiente interno, identificando suas forças e fraquezas, conduzida por questões de o quanto o recurso tem valor, é raro, é difícil de imitar e se a organização está agrupada de maneira a explorá-lo adequadamente. Sendo assim, os critérios a serem analisados são; o jogo do qual é proprietária, League of Legends e o modelo de funcionamento atual da liga.

\subsubsection{Valor}

A questão do valor diz respeito a capacidade que uma empresa possui de fazer seus recursos e capacidades serem bem utilizados para explorar as oportunidades e neutralizar as ameaças. Dessa forma, o LoL apresenta muito valor para a organização, passando dez anos desde a seu lançamento, o jogo continua no topo de plataformas de streaming, tem o maior fluxo diários de usuários comparado com os competidores e, no Brasil, apresenta a maior audiência em uma liga oficial. "Essa afirmação é sustentada por dados oficiais da Riot Games, que revelam que o pico diário de jogadores simultâneos é de cerca de 8 milhões. [...] A Riot destacou que o número supera os 10 jogos mais populares da Steam somados. De acordo com a página de estatísticas da plataforma, o pico diário destes títulos é de quase 2,3 milhões." (Mais Esports, 2019). Esses números mostram o quão forte é o jogo em questão de pessoas engajadas, fazendo com que o produto se torne valioso.

Em relação ao modelo atual de campeonato encontrado no CBLOL, a Riot não consegue aproveitar as oportunidades do setor e também não é efetiva em neutralizar ameaças. Isso acontece, pois, o modelo é bem básico, as organizações criam times, recrutando jogadores e comissão técnica, podem comprar uma vaga de outra equipe que já participa da liga ou entrar por torneios de acesso. Com todos definidos, os times se enfrentam até que os quatro primeiros se classificam para as semifinais e depois para a final. Outros 
campeonatos principais de outra modalidade também adotam essa maneira de organizar, como o Campeonato Brasileiro de Rainbow Six, praticamente apresentam as mesmas características, coincidentemente também há a presença de duas organizações que também tem um negócio no CBLOL. Dessa maneira, o modelo não apresenta valor para a desenvolvedora do League of Legends, pois ela não apresenta nada que a diferencie dos demais.

\subsubsection{Raridade}

Começando pelo League of Legends, no mercado a quantidade de jogos que são lançados impressiona, e em paralelo, alguns são parecidos com o LoL, apresentam as mesmas características, como um jogo de MOBA, ou seja, os jogadores se reúnem com outros para batalhar em uma arena destruindo estruturas, até que a equipe vencedora destrua a principal. Com isso, é possível identificar que outras empresas possuem acesso aos mesmos recursos que a Riot possui, seja um jogo diferente ou parecido. Exemplos de jogos que são MOBAs criados ao longo dos anos e seus respectivos anos de lançamento são; DOTA 2, Heroes of the Storm, Smite, Arena of Valor em 2012, 2013, 2014 e 2016. Essas circunstâncias afirmam que não á raridade de recursos no setor, pois os concorrentes possuem os mesmos acessos, porém quem tem mais investimento conseguem maior qualidade no produto.

Já o modelo do CBLOL também não se caracteriza como um recurso raro, devido a mesma questão do LoL, outras organizações possuem os mesmos recursos para fazer uma transmissão acessível, ao vivo ao público, e organizando as datas da competição de maneira agradável para quem assiste e joga. Um concorrente a altura é o CBCS, liga de Counter Strike, é transmitida também pelo SPORTV semanalmente pelo horário noturno, onde os jogadores se deslocam até o estúdio para jogar usando os mesmo computadores de todos, não criando alguma vantagem. Dessa forma, o modelo que o CBLOL apresenta não é raro, já que outras equipes também possuem os mesmos recursos, utilizando para melhor maneira de realizar o programa.

\subsubsection{Imitabilidade}

Com o fato de que não é raro de conseguir recursos para fazer jogos, as empresas conseguem o material devido para desenvolver novos produtos, sendo assim o League of Legends sofre com novos concorrentes no mercado, já que 
novos jogos foram lançados com características muito similares. Alguns exemplos e seus respectivos anos de lançamento são; DOTA 2, Heroes of the Storm, Smite, Arena of Valor em 2012, 2013, 2014 e 2016. Dessa forma, o LoL é facilmente copiado, podendo prejudicar na competição. A Tencent "imitou" o League of Legends, lançando o Arena of Valor para celular, explorando o mercado que não era de nenhuma empresa, já que a Riot só apresenta seu produto para computadores, assim pessoas que não possuem acesso a essas máquinas mais desenvolvidas podem jogar um game ao estilo de LoL na palma da mão, com os smartphones. Depois de 2 anos do surgimento de Arena of Valor, a Riot Games anunciou que estará colocando no mercado em 2020 o League of Legends de celular, indo contra sua palavra, pois no passado afirmou que o jogo não poderia ser replicado em smartphones, podendo ser uma evidência de que o setor de jogos mobile não são de ignorar.

Já o modelo de CBLOL é muito fácil de ser imitado, antes mesmo da liga vir ao mercado outros torneios seguiam os mesmo moldes, estes sendo esportes tradicionais, como na liga norte americana de futebol americano, a NFL. Ligas que surgiram após o CBLOL e usam o mesmo modelo são o campeonato brasileiro de Rainbow Six Siege, o circuito brasileiro de Counter Strike. Isso acontece pois não há recursos que sejam difíceis de encontrar com fornecedores que cumpra com $o$ que as empresas precisam, como por exemplo computadores, um estúdio para transmissão das partidas, narradores, comentaristas dentre outros.

\subsubsection{Organização}

Essa questão julga se a empresa está organizada adequadamente para explorar ao máximo a capacidade dos recursos e capacidades em criar vantagem competitiva. A respeito do League of Legends, a Riot faz um grande trabalho desenvolvendo e sempre atualizando o jogo, com o intuito de deixá-lo mais atrativo para quem já joga e para quem está começando.

"Primeiro que o jogo é de graça, apesar de poder comprar cosméticos no jogo, isso não muda em jogabilidade. Eles mudam o jogo constantemente, isso é bom que dá uma variada, não fica algo maçante, toda partida pode ser diferente, não é que nem COD que você joga sempre a mesma coisa e acaba enjoando." (Rodrigo "RV17" Veras -expectador de League of Legends). 
"Acho que ela já faz isso muito bem, muito bem mesmo, o tanto de skin que vem lançando, modos de jogos urf voltando está ai pra provar isso) e agora esses milhares de jogos lançando vai fazer todo mundo voltar a ver LoL com outros olhos, todo ano sempre muda também, mil atualizações, nesse ponto a Riot trabalha muito bem e com isso aumentando pra caramba o ciclo de vida." (Emerson "BocaJR" Alencar - jogador profissional de League of Legends).

Isso demonstra o quão preparada está a organização para ligar com as ameaças do ambiente e também a gerir o produto, desenvolvendo novas funcionalidades dentro do jogo, novos itens para os jogadores comprarem com dinheiro, além de manter uma história por trás, fazendo com que as pessoas se identifique com algum personagem em específico, nos mais de 150 que possuem dentro de League of Legends

Já em relação ao modelo do CBLOL, a empresa também tem um bom aproveitamento, sendo organizada de maneira que os clientes possam sempre estar em contato com os jogos da liga, além de criar climas específicos para partidas, como por exemplo algum clássico, ou jogo decisivo para passar à outra fase. Além do CBLOL que é transmitido sábado e domingo a partir das 13hrs, ao longo da semana há dois programas para deixar o público com maior contato dos jogos, que são o "Depois do Nexus", com transmissão às segundas às 20 horas, que faz um resumo do que aconteceu na liga no fim de semana anterior, com comentaristas e convidados, que são geralmente jogadores e o "League News", transmitido quarta também às 20 horas, que mostra a situação de outras ligas de League of Legends no mundo, sempre criando um costume ao público, dando mais opções de consumo.

"O marketing é muito poderoso, com trailers que atraem as pessoas, músicas feitas para o jogo, despertando sempre a vontade de jogar. Também em relação aos campeonatos, conseguem deixar todos animados com trailers, transmissões com jogos bem disputados." (Germano "Hunbaut" Pereira - Espectador de League of Legends) 
Tabela 1 - Análise VRIO

\begin{tabular}{|l|l|l|l|l|l|}
\hline Recursos & Valioso? & Raro? & $\begin{array}{l}\text { Custoso } \\
\text { de imitar? }\end{array}$ & $\begin{array}{l}\text { Explorado pela } \\
\text { organização? }\end{array}$ & $\begin{array}{l}\text { Implicações } \\
\text { competitivas }\end{array}$ \\
\hline League of Legends & Sim & Não & Não & Sim & $\begin{array}{l}\text { Paridade } \\
\text { competitiva }\end{array}$ \\
\hline Modelo do CBLOL & Não & Não & Não & Sim & $\begin{array}{l}\text { Desvantagem } \\
\text { competitiva }\end{array}$ \\
\hline
\end{tabular}

Com a análise VRIO, pode-se perceber que o jogo League of Legends faz com que a Riot tenha paridade competitiva no mercado, pois ele é valioso, apresenta grande quantidade de jogadores e audiência em sites especializados para assistir jogos, além de ser bem aproveitado, explorando ao máximo as suas capacidades, mantendo os consumidores entretidos e fieis durante dez anos de existência.

Já o modelo de como funciona o CBLOL não apresenta nenhuma vantagem a empresa, pois ele é facilmente copiado por competidores, uma vez que várias ligas utilizam o mesmo método ou um muito parecido para organizar os jogos e transmitir o meio de entretenimento. A Riot Games precisa mudar a maneira de realizar o CBLOL para que ela se torne mais atrativa para quem assiste e para quem participa.

\subsection{Análise VRIO franquias no CBLOL}

Fazendo uma análise VRIO do CBLOL utilizando o modelo de franquia como base ao invés do modelo atual, é possível saber se o novo modo de o organizar terá vantagem à respeito dos concorrentes, o quão bom ou ruim será, se éuma boa estratégia adotá-lo.

\subsubsection{Valor do modelo de franquia}

O modelo apresenta um valor grande a Riot, pois ela consegue aproveitar uma oportunidade do setor, se tornando a pioneira no Brasil a seguir o modelo, consolidando mais ainda a modalidade e criando estabilidade às equipes devido às participações nos lucros que as organizações participantes terão, seja ela em receitas de eventos e patrocinadores, como por exemplo hoje que são a Gillette e a Dell, além de fazer com que os times usem a imagem do campeonato a seu 
favor, fazendo eventos e ganhando capital em torno disso. Além de estabilidade, já que as empresas estarão estruturadas para poderem planejar estratégias de longo também, já que o risco de perder a vaga não existe mais. Por fim, a premiação que aumenta de ano a ano, com mais investimentos, mais dinheiro tem para premiar, mais investimentos dos times, uma maior qualidade dos jogadores e consequentemente na partida, fazendo com que o público se anime mais e a audiência aumente, todo um ciclo que faz o CBLOL ter mais valor ainda do que antes, criando benefícios aos clientes que não teriam em nenhuma outra liga de esport no Brasil.

"Acredito que franquia é um modelo que dá resultado em outras ligas do mundo e que pode ser adequado ao CBLOL também, falando de um aspecto de negócio, não sei dizer as diferenças para adaptar para a nossa liga."

"Pontos positivos estão na maior garantia de investimento na liga, dado que os times vão permanecer e que a tendência é que o interesse do público pela mesma não diminua. Sobre os pontos negativos, acredito que o importante é que é um passo que dificilmente será dado de volta, então é necessário preparar tudo muito bem antes para não implodir o ecossistema." (Gustavo "gstv" Cima - comentarista de League of Legends).

\subsubsection{Raridade no modelo de franquias}

No quesito raridade, o modelo é raro no mercado, pois poucos concorrentes implementam o modelo, no Brasil nenhuma empresa implantou esse sistema nas organizações de campeonatos, tendo os times como parte dos sócios, porém o modo de realizar é simples, há uma premissa da qual seguida pode ser estabilidade.

\subsubsection{Imitabilidade no modelo de franquias}

Em questão ao custo de imitar, esse já é elevado e difícil de se realizar, pois é preciso que uma liga se estabeleça no mercado, com uma grande audiência e que os consumidores tenham frequência de assistir, mostrando aos times e organizações que vale a pena investir uma grande quantidade de dinheiro para comprar uma vaga. É um modelo que funciona quando a liga já é estável e não representa riscos altos aos investidores, que estão interessados 
em quantas pessoas a atividade de entretenimento consegue alcançar, sendo assim é custoso de se imitar.

\subsubsection{Organização no modelo de franquias}

Por fim, a respeito do quão preparado a organização está para realizar, a Riot Games já vem de experiências de outros países, como suas ligas franqueadas nos Estados Unidos e na Europa, mostrando que tem capacidade de organizar um modelo dessa forma internacionalmente. Atualmente no Brasil seu trabalho é impecável, como mostrado em opiniões anteriores, a empresa consegue administrar e manter o público constantemente interessado, sendo assim, se juntando com experiências internacionais e com o modelo de gestão atual, a empresa conseguirá explorar o recurso no Brasil.

Tabela 1 - Análise VRIO franquias no CBLOL

\begin{tabular}{|l|l|l|l|l|l|}
\hline Recursos & Valioso? & Raro? & $\begin{array}{l}\text { Custoso } \\
\text { de imitar? }\end{array}$ & $\begin{array}{l}\text { Explorado pela } \\
\text { organização? }\end{array}$ & $\begin{array}{l}\text { Implicações } \\
\text { competitivas }\end{array}$ \\
\hline Franquia no CBLOL & Sim & Sim & Sim & Sim & $\begin{array}{l}\text { Vantagem } \\
\text { competitiva } \\
\text { sustentável }\end{array}$ \\
\hline
\end{tabular}

A tabela mostra o quão o modelo de organização do CBLOL muda de forma, deixando-o muito atrativo e tendo vantagem competitivo sustentável a outras ligas do Brasil, devido a estrutura que possui, os benefícios às organizações que aderirem o modelo e a dificuldade que os concorrentes têm de imitar, pois é preciso uma estruturação e para os investidores sentirem seguros a injetar dinheiro, além de um campeonato estável. 


\section{Conclusão}

O mercado de Esports no Brasil se encontra em crescimento, com todo ano lançando algum jogo no mundo, criando um alerta ao League of Legends e sua liga no Brasil, o Circuito Brasileiro de League of Legends. Mas como observado nas pesquisas, vários games apareceram, ameaçando o reinado do LoL, porém com o tempo eles foram sendo esquecidos e deixados de serem jogados pelos usuários, sobrando apenas as ligas que foram bem estruturadas como o Campeonato de Rainbow Six e o Campeonato de Counter Strike, entretanto em termos de audiência esses campeonatos ainda estão longe do que o CBLOL alcançou e que pode vir a alcançar, dessa forma se mostra um mercado muito promissor para a Riot Games, demonstrando que pode haver uma liderança no setor durante alguns anos, baseado na análise das forças de Porter.

Já na análise interna, os recursos analisados foram o próprio jogo que mantém a liga em funcionamento, o League of Legends, e o modelo que o torna em funcionamento. Foi visto que o LoL tem uma paridade competitiva com outros jogos, apesar de ser um dos jogos mais jogados do mundo e do Brasil, ele ainda sofre ameaça de concorrentes, novos entrantes e até de produtos substitutos, fazendo com que alguém possa copiá-lo com maior qualidade, já que pela análise VRIO é possível observar que isso é possível, já que os competidores tem acesso aos mesmos recursos. Em relação ao modelo que é apresentado na liga, o CBLOL é muito ameaçado, porque vários torneios seguem esse mesmo modelo, inclusive os consolidados no mercado como o Campeonato de Rainbow Six e o Campeonato de Counter Strike, ou seja, a Riot não oferece nenhum objetivo a mais, além de mais visibilidade às equipes que participam do torneio, inclusive algumas dessas estão presentes nesses dois outros citados.

Porém, como visto em outra análise VRIO, a estrutura do CBLOL montada em torno de franquias faz com que a Riot possua vantagem competitiva sustentável em relação as outras, devido ao fato de oferecer novos benefícios para as organizações que decidem competir no torneio, criando estabilidade aos times, além de maior fonte de receitas, com participação nos lucros e também 
uso de imagem para realizar eventos pelo país, deixando bastante atrativo em questão de negócio para os investidores. Dessa forma, o futuro do CBLOL ser pautando em franquias é bom para a organizadora e bom para os clientes, seja eles os investidores e seja eles os clientes, porque com mais dinheiro entrando, melhor qualidade fica o torneio, sendo investido em categorias de base, nascendo novos talentos e sempre renovando o cenário, levando a mais jogos emocionantes, criando um ciclo onde todos se beneficiam. O modelo se torna valioso para a Riot, além de ser difícil de imitar, pois demanda de muito investimento das organizações, e confiança para que possam injetar a quantidade de dinheiro necessária, confiança que é conquistada através de números de audiência e tempo de vida do produto, duas características que o CBLOL consegue entregar e as outras ligas de Esports do país não. 


\section{Referências Bibliográficas}

CACOPHONIE. Novidades para o Circuito Desafiante 2020. LoL Esports BR. 23 out. 2019. Disponível em <https://br.lolesports.com/noticias/novidades-para-ocircuito-desafiante-2020> Acesso em 1 nov. 2019

CONFEDERAÇÃO BRASILEIRA DE ESPORTS. Entenda a futura Liga Overwatch e o sistema de Franquias. Confederação Brasileira de Esports. Disponível em: <http://cbesports.com.br/artigos/entenda-a-futura-liga-overwatche-o-sistema-de-franquias/> Acesso em 1 nov. 2019

DE ABREU, V. CBLoL 2019: veja tabela de datas, times e regulamento do $2^{\circ}$ split. TechTudo. 31 mai. $2019 . \quad$ Disponível em: <https://www.techtudo.com.br/noticias/2019/05/cblol-2019-veja-tabela-de-datastimes-e-regulamento-do-2o-split-esports.ghtml> Acesso em 1 nov. 2019

DOTA 2. The International. DOTA 2, 24 jul. 2019. Disponível em: <http://www.dota2.com/international/overview/> Acesso em 1 nov. 2019

EQUIPE POKERSTARS Uma breve história dos eSports. PokerStars Blog, 09 mar. 2018 Disponível em: <https://www.pokerstars.com/br/blog/news/2018/post9-171173.shtml?no_redirect=1> Acesso em 26 set. 2018

FALK C. Com mais de $\mathbf{1 1 0}$ mil espectadores, Yoda bate recorde durante transmissão. Streamie. 29 set. 2019. Disponível em: <https://streamie.com.br/yopresidente/> Acesso em 1 nov. 2019

GUERRA, F. O que é MOBA? Confira significado e games de sucesso no competitivo. Sportv. 02 abr. 2019. Disponível em: $<$ https://sportv.globo.com/site/e-sportv/noticia/o-que-e-moba-confira-significadoe-games-de-sucesso-no-competitivo.ghtml> Acesso em 1 nov. 2019 
JUNQUEIRA, D. O que aconteceu com as Lan Houses no Brasil? Olhar Digital, 21 ago. 2012. Disponível em <https://olhardigital.com.br/noticia/lanhouses-as-casas-de-jogos-se-tornaram-centros-de-inclusao-digital/28528> Acesso em 26 set. 2018

KOTLER E KELLER. Administração de marketing. São Paulo 2012

JAY B. BARNEY E WILLIAM S. HERSTERLY. Administração Estratégica e Vantagem Competitiva. São Paulo 2011

LIQUIPEDIA Brasileirão 2019. Liquipedia. 04 ago. 2019. Disponível em <https://liquipedia.net/rainbowsix/Brasileir\%C3\%A3o/2019> Acesso em 1 nov. 2019

LOL ESPORTS BR. Final do CBLoL bate recorde de audiência em 2019. LoL Esports BR. 07 out. 2019 Disponível em: <https://br.lolesports.com/noticias/finaldo-cblol-bate-recorde-de-audiencia-em-2019> Acesso em 1 nov. 2019

LOL ESPORTS BR. Os números dos eventos de LoL Esports 2017. LoL Esports BR, 19 dez. 2017. Disponível em <https://br.lolesports.com/noticias/osnumeros-dos-eventos-do-lol-esports-2017> Acesso em 26 set. 2018

MARQUES, R. LoL: Pico diário de jogadores é de 8 milhões, diz Riot. Mais Esports. 17 set. 2019. Disponível em: <https://www.maisesports.com.br/lol-pico8-milhoes/> Acesso em 1 nov. 2019

MARTINS, B. R6: Liquid aparece em todos os seis jogos de maior audiência da Pro League. Mais Esports 17 out. 2019 Disponível em: $<\mathrm{https}$ ://www.maisesports.com.br/r6-liquid-jogos-audiencia-pro-league/> Acesso em 1 nov. 2019

MEIRELES, J. Conheca a Inferno Online - a maior lan house do planeta. Gameblast, 23 jan. 2016. Disponível em $<$ https://www.gameblast.com.br/2016/01/conheca-inferno-online.html> Acesso em 26 set. 2018 
MITKE, P. Dota 2: OG vence Liquid e é campeã do The International 2019. Mais Esports, 25 ago. 2019. Disponível em: $<$ https://www.maisesports.com.br/og-campea-the-international-2019/> Acesso em 1 nov. 2019

MYCNB. Primeiros donos de franquias da Liga de Overwatch são anunciados. Mycnb. Disponível em: http://uol.webapp.mycnb.com.br/noticias/5821-primeiros-donos-de-franquias-daliga-de-overwatch-sao-anunciados> Acesso em 1 nov. 2019

NEWZOO \& ESPORTS BAR. ESPORTS IN BRAZIL: KEY FACTS, FIGURES, AND FACES. 2018

PANNEKEET, J. Newzoo: Global Esport Economy Will Reach $\$ 905$ Million in2018 as Brand Investment Grows by 48\%. Newzoo, 21 fev. 2018. Disponível em <https://newzoo.com/insights/articles/newzoo-global-esports-economy-willreach-905-6-million-2018-brand-investment-grows-48/> Acesso em 26 set. 2018

PEDROSO, A. A Lenovo é a nova patrocinadora do campeonato brasileiro de Rainbow Six 2019. Adrenaline. 14 mar. 2019. Disponível em: <https://adrenaline.uol.com.br/noticias/v/58364/a-lenovo-e-a-nova-patrocinadorado-campeonato-brasileiro-de-rainbow-six-2019> Acesso em 1 nov. 2019

PORTINARI, N. Fim das lan houses deixou lacuna, diz pioneiro do setor. Folha de São Paulo, 16 jul. 2017. Disponível em <https://m.folha.uol.com.br/mercado/2017/07/1901623-fim-das-lan-housesdeixou-lacuna-diz-pioneiro-do-setor.shtml> Acesso em 26 set. 2018

PUIATI, J. League of Legends: LCS Europa anuncia sistema de franquias. TechTudo. 03 abr. 2019. Disponível em: <https://www.techtudo.com.br/noticias/2018/04/league-of-legends-lcs-europaanuncia-sistema-de-franquias.ghtml> Acesso em 1 nov. 2019

RIGON, D. "Modelo de franquia não é a solução para o CBLoL agora", diz Riot. ESPN. 10 jan. 2019. Disponível em <https://www.espn.com.br/esports/artigo/_/id/5157416/modelo-de-franquia-naoe-a-solucao-para-o-cblol-agora-diz-riot> Acesso em 1 nov. 2019 
ROMER, R. Final do CBLoL 2019 bate recorde de audiência com 300 mil espectadores. The Enemy. 08 out. 2019. Disponível em: $<$ https://www.theenemy.com.br/esports/final-do-cblol-2019-bate-recorde-deaudiencia-com-300-mil-espectadores> Acesso em 1 nov. 2019

SANTOS, A. Final do CBLoL entre Flamengo e INTZ acontece sábado no Rio. Terra. 3 set. $2019 . \quad$ Disponível em: <https://www.terra.com.br/diversao/games/esports/final-do-cblol-entre-flamengoe-intz-acontece-sabado-norio,f30790f9d84a32451def9f0c104ebbfasyz4xqbw.html> Acesso em 1 nov. 2019

SEBRAE. Conheça o sistema de franquias. Sebrae. Disponível em: <http://www.sebrae.com.br/sites/PortalSebrae/artigos/conheca-o-sistema-defranquias,6c9b39407feb3410VgnVCM1000003b74010aRCRD> Acesso em 1 nov. 2019

SPORTV.COM. Estudo: Brasil segue como terceiro maior público cativo de e-sports do mundo. Sportv, 21 fev. 2018. Disponível em $<$ https://sportv.globo.com/site/e-sportv/noticia/estudo-brasil-segue-como-terceiromaior-publico-cativo-de-e-sports-do-mundo.ghtml> Acesso em 26 set. 2018

SPORTV.COM. League of Legends: Riot atualiza logo do game e revela número impressionante de jogadores. Sportv. 17 set. 2019. Disponível em: $<$ https://sportv.globo.com/site/e-sportv/lol/noticia/league-of-legends-riot-atualizalogo-do-game-e-revela-numero-impressionante-de-jogadores.ghtml> Acesso em 1 nov. 2019

SUPERDATA RESEARCH. The success of Fortnite Battle Royale is big enough to share. Superdata, 17 jul. 2018. Disponível em $<$ https://www.superdataresearch.com/the-success-of-fortnite-battle-royale-is-bigenough-to-share/> Acesso em 26 set. 2018

TEIXERA, V. Conheça Pong, o primeiro videogame lucrativo da história. Tech Tudo, 07 mar. $2016 . \quad$ Disponível em: <https://www.techtudo.com.br/noticias/noticia/2016/03/conheca-pong-o-primeirovideogame-lucrativo-da-historia.html> Acesso em 26 set. 2018 
VENTURA, V. Parceria com Gillette: o novo momento da Riot Games. MyCNB, 09 set. 2018. Disponível em <http://mycnb.uol.com.br/noticias/6547parceria-com-gillette-o-novo-momento-da-riot-games> Acesso em 26 set. 2018

VENTURA, V. 2o split do CBLoL é o $4^{\circ}$ torneio de LoL mais assistido na Twitch e YouTube, afirma site. Mais Esports. 24 set. 2019. Disponível em: <https://www.maisesports.com.br/lol-2-split-cblol-4otorneio-mais-assistido/> Acesso em 1 nov. 2019

WIKIPÉDIA. PC bang. Wikipédia, 13 jul. 2017. Disponível em: <https://pt.wikipedia.org/wiki/PC_bang> Acesso em 26 set. 2018

\subsection{Questionário}

1) Qual a importância do CBLOL para você? E do Circuito Desafiante?

2) Você torce para algum time do CBLOL? Isso influencia na sua decisão de assistir o CBLOL?

3) A Riot Games iniciou conversas com as principais equipes para a implementação de franquias no CBLOL a médio prazo, o que você acha sobre essa questão? Quais os pontos positivos e negativos?

4) Com o modelo implementado, uma das consequências será a extinção do Circuitão, já que nenhum time da liga principal irá ser rebaixado, o que isso influenciará nas organizações? Quais as consequências para o público que assiste as competições (CBLOL e Circuito Desafiante)?

5) Na sua opinião, é vantajoso para equipes investirem comprando uma vaga do CBLOL mesmo sabendo que o jogo já apresenta bastante anos de vida, podendo ser ultrapassado por outro jogo em questão de visualizações e moda?

6) Qual a influência que o terá o CBLOL sendo franqueado em relação às outras ligas de Esports do Brasil, como você acha que elas irão agir? 
7) Como você vê a gestão da Riot para que ela possa deixar o jogo mais atrativo, aumentando o clico de vida do produto?

8) Você acha que outra liga de E-sport possa passar o CBLOL em questão de importância, por exemplo, visualizações, investimento e etc?

9) Com esse modelo de franquias, é necessário um grande porte de capital por meio das equipes, você acha que as organizações estarão prontas financeiramente para esse modelo?

10) Você acha que as equipes existentes e as futuras equipes que entrarão no negócio são preparadas para gerir o negócio? 